
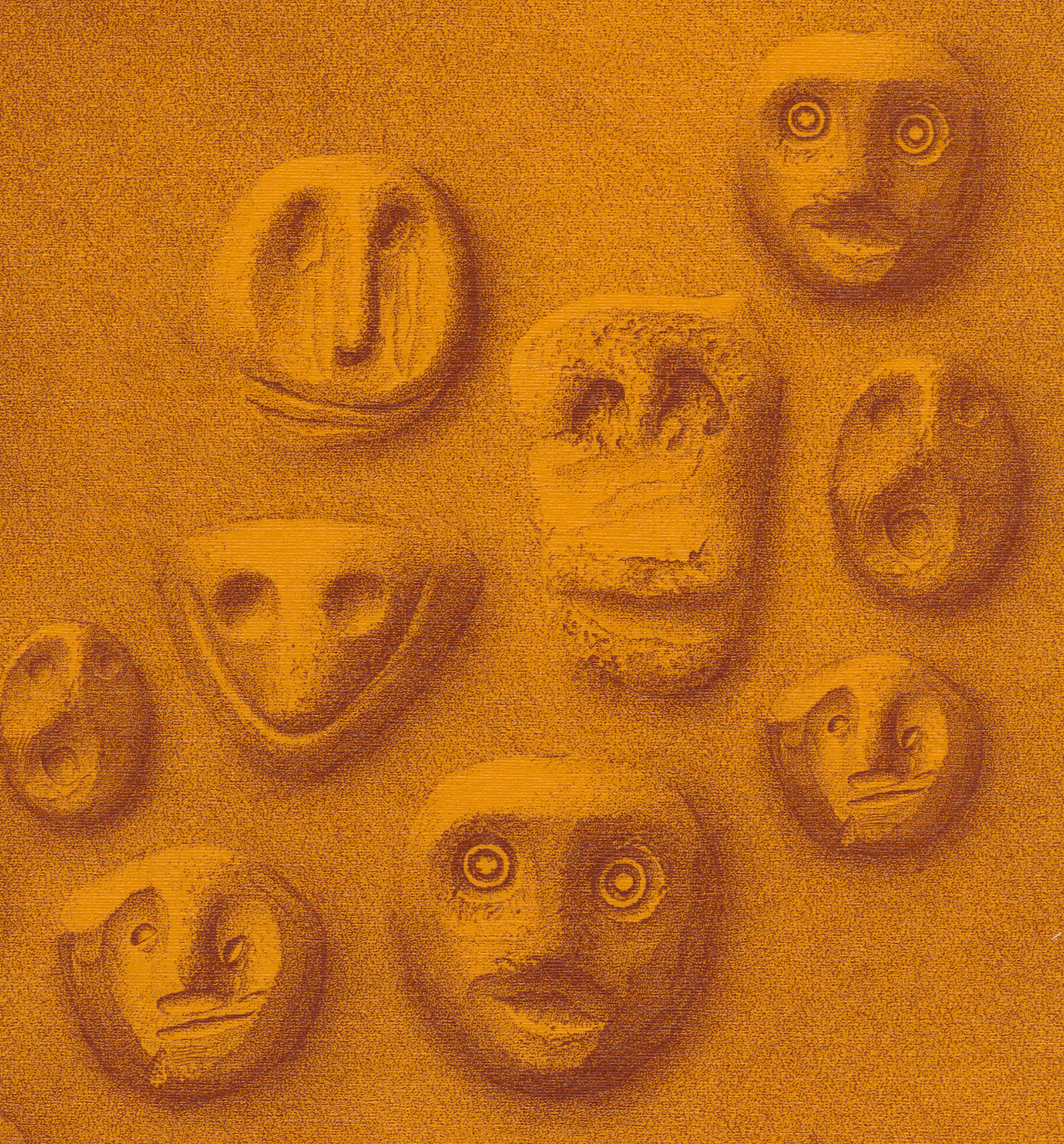

5) - Nethe

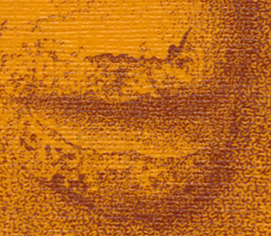




\section{KUML 1990}

Årbog for Jysk Arkæologisk Selskab

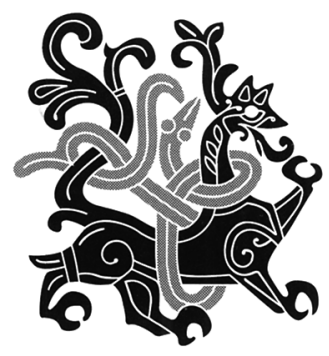

With summaries in English

I kommission hos Aarhus Universitetsforlag, Århus 
Redaktion: Poul Kjarum

Redaktionsudvalg:

Jens Henrik Bech, Thisted

Steen Hvass, Vejle

Stig Jensen, Ribe

Erik Johansen, Aalborg

Erik Jorgensen, Haderslev

Hans Jorgen Madsen, Arhus

Omslag: Lerhoveder fra celdre jernalder

Udgivet med stotte af Statens Humanistiske Forskningsråd

Omslag: Jens Kirkeby

Grafisk tilretteloggelse: Elsebet Morville

Tryk: Special-Trykkeriet Viborg a-s

Skrift: Bembo 11/12

Papir: Stora G-Print $120 \mathrm{~g}$

Copyright 1992 by Jysk Arkceologisk Selskab

ISBN 87-7288-562-9

ISSN 0454-6245 


\section{Indhold/Contents}

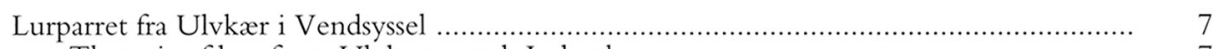

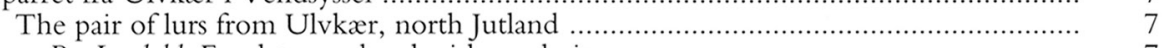

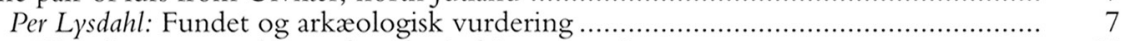

The discovery and its archaeological interpretation ................................. 21

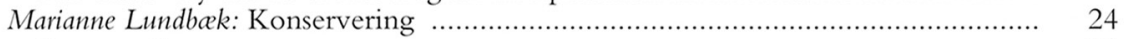

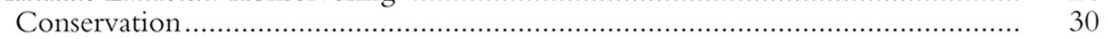

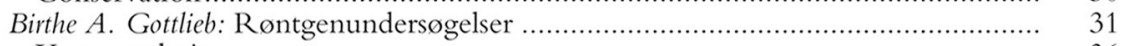

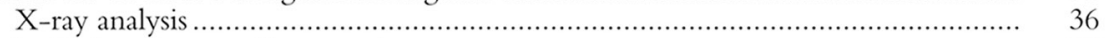

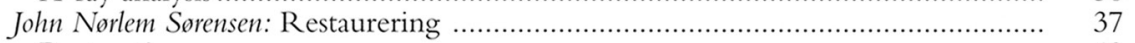

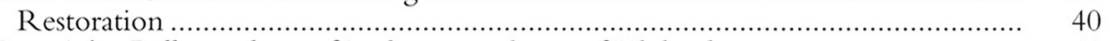

Bent Aaby: Pollenanalyser af jordprøver udtaget af Ulvkærlurerne ............................. 41

Pollen analysis of peat samples from the Ulvkær lurs .............................. 42

Erik Johansen: En brandgravplads med smykkefund fra førromersk jernalder.................... 45

A cremation cemetery with ornaments from the pre-Roman Iron Age ...................... 56

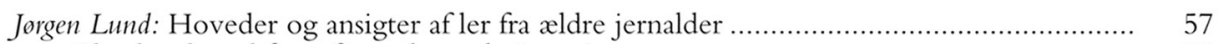

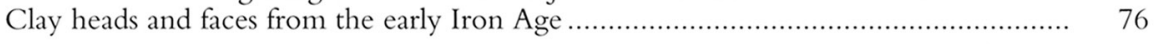

Lise Bender Jørgensen: Hørvævninger og oldtidsvæve ......................................... 77

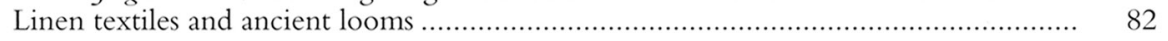

Per Ethelberg: To grave fra Højvang, Sønderjylland .............................................. 85

Dendrodatering og absolut kronologi

Two graves from Højvang in southern Jutland; dendrodating and

absolute chronology

John Brinch Bertelsen: Nederby på Fur - en landsby grundlagt i yngre jernalder

Et bidrag til belysning af vikingetidsbebyggelsen i den vestlige del af Limfjorden ........

Nederby on Fur, a village founded in the later Iron Age. A contribution to

knowledge of Viking settlement in the western Limfjord

Torben Nilsson: Stentinget. En indlandsbebyggelse med handel og håndværk fra

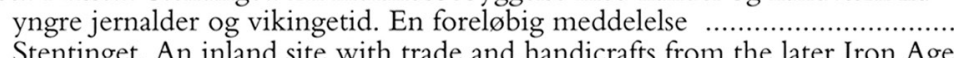

Stentinget. An inland site with trade and handicrafts from the later Iron Age.

A preliminary notice.

H. J. Madsen og Per Vegger: Karby på Mors. En landsby fra vikingetiden

Karby on Mors, a Viking village ....

En vikingetidssølvskat fra Brokhøj, Gjerrild Klint

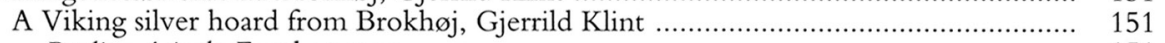

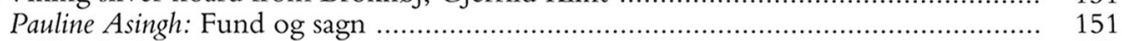

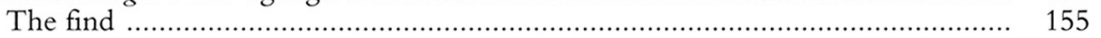

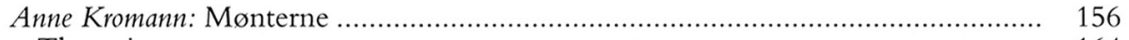

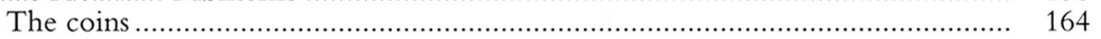




\title{
Nederby på Fur - en landsby grundlagt i yngre jernalder \\ Et bidrag til belysning af vikingetidsbebyggelsen i den vestlige del af Limfjorden
}

\author{
Af JOHN BRINCH Bertelsen
}

Gennem de sidste par årtier har arkæologien for alvor forøget vor viden om, hvornår vores nuværende landsbyer blev grundlagt. Påvisningen af de store vikingetidslandsbyer ved Trabjerg, Sædding, Omgård og Vorbasse gjorde det klart, at disse lå i nogen afstand fra de efterfølgende middelalderlandsbyer (1). Dette blev understreget gennem det fynske landsbyprojekt i årene 1975-79. Her blev der lavet små dateringsgravninger i 13 landsbyer. Det var ikke muligt at bekræfte stednavneforskernes teorier om, at disse landsbyer kunne føres tilbage til tiden for vikingetiden. De syntes næsten alle grundlagt i begyndelsen af den tidlige middelalder (2). Samme resultat havde en tilsvarende undersøgelse $i$ Århus Amt 1985 (3). Det synes derfor velbegrundet at tale om et generelt kontinuitetsbrud og bebyggelsesskift på overgangen mellem vikingetid og tidlig middelalder.

At der dog er undtagelser fra denne hovedregel, er Nederby på Fur et godt eksempel på. Her har tre års udgravninger givet det overraskende resultat, at den nuværende landsby synes grundlagt allerede i yngre germansk jernalder (4). I det følgende skal udgravningsresultaterne fremlægges og herefter vil de afvigende forhold på Fur blive vurderet. Herunder inddrages de øvrige vikingetidsbebyggelser fra den vestlige del af Limfjordsområdet (fig. 1).

\section{Udgravningerne i Nederby}

Landsbyen Nederby ligger på Sydfurs flade land, helt ud mod den østvendte kyst (fig. 2). Landsbyen ligger på to ca. 10 meter høje bakketunger, der er adskilt fra kysten af en markant nord-syd gående littorinaskrænt, og øst for denne en ca. 50 meter bred strandeng. På en tredie bakketunge lige syd for landsbyen ligger øens sognekirke, Sct. Mortens Kirke, der er opført omkring år 1126 (5).

Fra 1987-89 udgravedes $1100 \mathrm{~m}^{2}$ på Bjerregårdsbakke i den nordlige del af Nederby og $4400 \mathrm{~m}^{2}$ i den sydlige del ved Fur Kirkevej (fig. 2). Endelig blev der udlagt en 80 meter lang søgegrøft nordvest for landsbyen og tre små prøvefelter á 50-100 $\mathrm{m}^{2}$ nord for landsbyen. Fra de to hovedfelter er i alt fremkommet 28 grubehuse, 2 langhuse, grøftsystemer samt et stort antal gruber. Søgegrøften nordvest for landsbyen rummede tillige mange anlægsspor, hvorimod de tre små prøvefelter var fundtomme. Hertil kommer en lang række tilfældige 


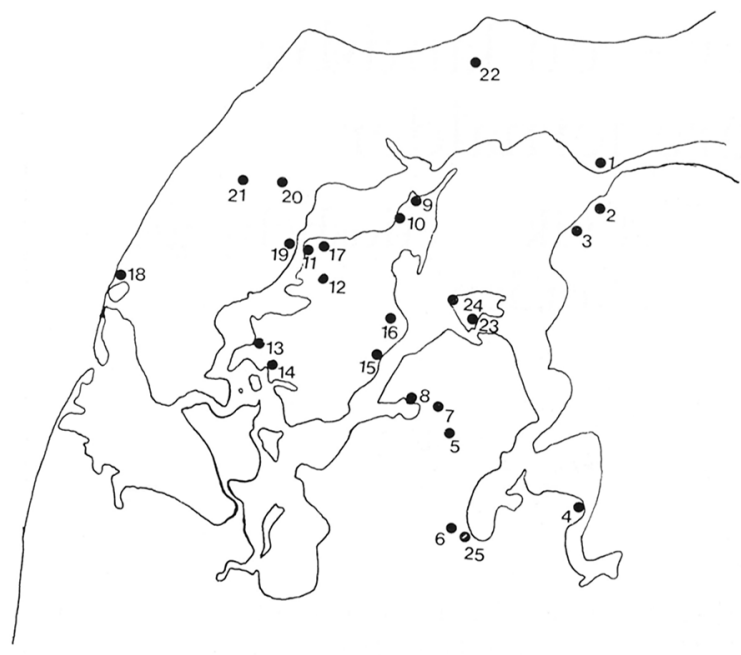

Fig. 1. Bebyggelser fra yngre germanertid og/eller vikingetid i den vestlige del af Limfjorden. Nr. 23 er Nederby. Numrene henviser til fundlisten. Tegning: Sonja Justensen.

Settlement from the later

Germanic/Viking periods in the western part of the Limfjord. No. 23 is Nederby. The numbers refer to the list of sites.

fund, fremkommet under nybyggeri, især ved udbygningen af parcelhuskvarteret på Bjerregårdsbakke siden 1971 .

Sammenfattes alle disse iagttagelser kan det anslås, at oldtidsbebyggelsen har dækket et område på ca. 300 meter i nord-syd gående retning og minimum 250 meter øst-vest, i alt ca. $75.000 \mathrm{~m}^{2}$. Bebyggelsen er dog ikke afgrænset mod vest.

\section{Huse og stratigrafi}

\section{Langhuse}

Der kunne udskilles to langhuse med bevaret væglinie. Husene er af vidt forskellig konstruktion og datering.

Hus I er et treskibet langhus med buede langsider (fig. 3). Huset er godt 5 meter bredt ved gavlen og den nordlige væglinie kan følges over ca. 24 meter. Derimod er det meste af husets sydvæg og hele vestgavlen bortpløjet i nyere tid på grund af et meget tyndt mulddække netop her (6). End ikke de tagbærende stolper i husets vestende lader sig påvise. I den bevarede del af husets sydvæg kan der, 3-4 meter fra østgavlen, ses en indgang markeret med indtrukne dobbeltstolper. Lige vest herfor ses eet sæt kraftige tagbærende stolper. Endnu et sæt tagbærende stolper, omend mere spinkle, ses umiddelbart indenfor østgavlen, men ikke i selve gavlen.

Hus II er et 16 × 5,5 meter stort rektangulært langhus (fig. 3). Huset har hverken indre tagbærende stolper eller ydre, skrå støttestolper. Der er med andre ord tale om en enskibet konstruktion, hvor væggene har båret taget. I flere af de store rektangulære nedgravninger til vægstolperne iagttoges stolpespor efter 15-20 cm kraftigt, lodretstillet tømmer.

\section{Grubehuse}

Af de 28 grubehuse var der 25 ovale til cirkulære og 3 rektangulære. Alle grubehuse var øst-vest orienterede. Foruden de to tagbærende stolper havde en del af de cirkulære til ovale huse små nedhamrede pæle i vægforløbet. Hullerne var 


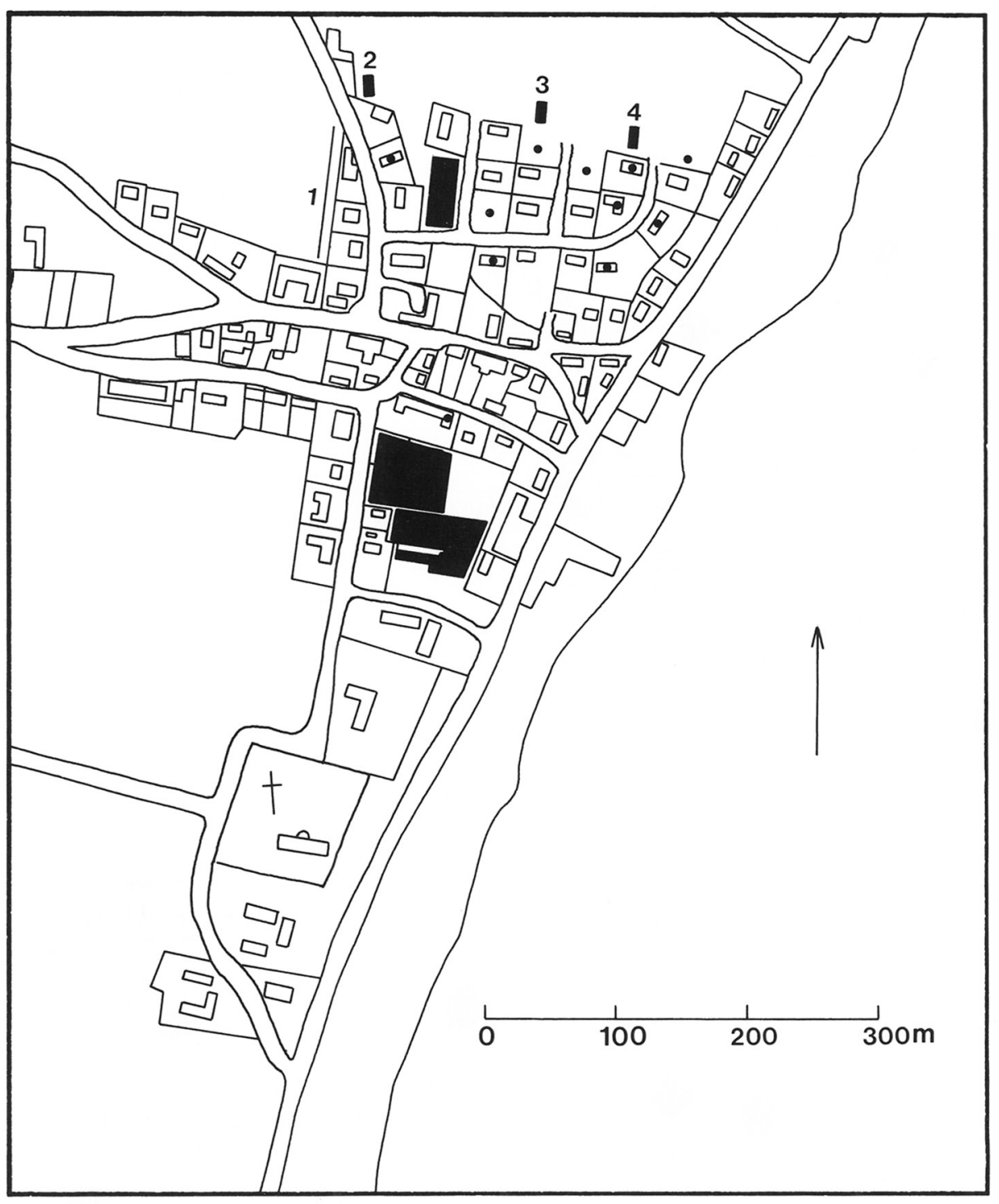

Fig. 2. Skitse over Nederby 1978 med angivelse af daværende veje og huse. Udgravningsfelterne er fremhævet med sort. Nr. 1 søgegrøft mod nordvest. Nr.2-4 prøvefelter mod nord, udfyldte cirkler angiver fund, der er fremkommet under byggeri. Tegning: Sonja Justesen.

Sketch of Nederby 1978, showing the then existing roads and houses. The excavated areas are shown in black. No. 1 northwestern trial trench. Nos. 2-4 northern cuttings, filled circles showing finds made during building work.

3-8 cm i diameter og 6-15 cm dybe. Enkelte af pælene var tilspidsede. Disse grubehuse må have haft risflettede vægge, der formodes at have båret en lerklining. Der kunne ikke påvises pælehuller i de rektangulære grubehuse, der må have haft en anden vægudformning, antagelig en bulkonstruktion. Grubehusene var gennemgående små med en diameter på 2,60-3,25 meter. De var kun 


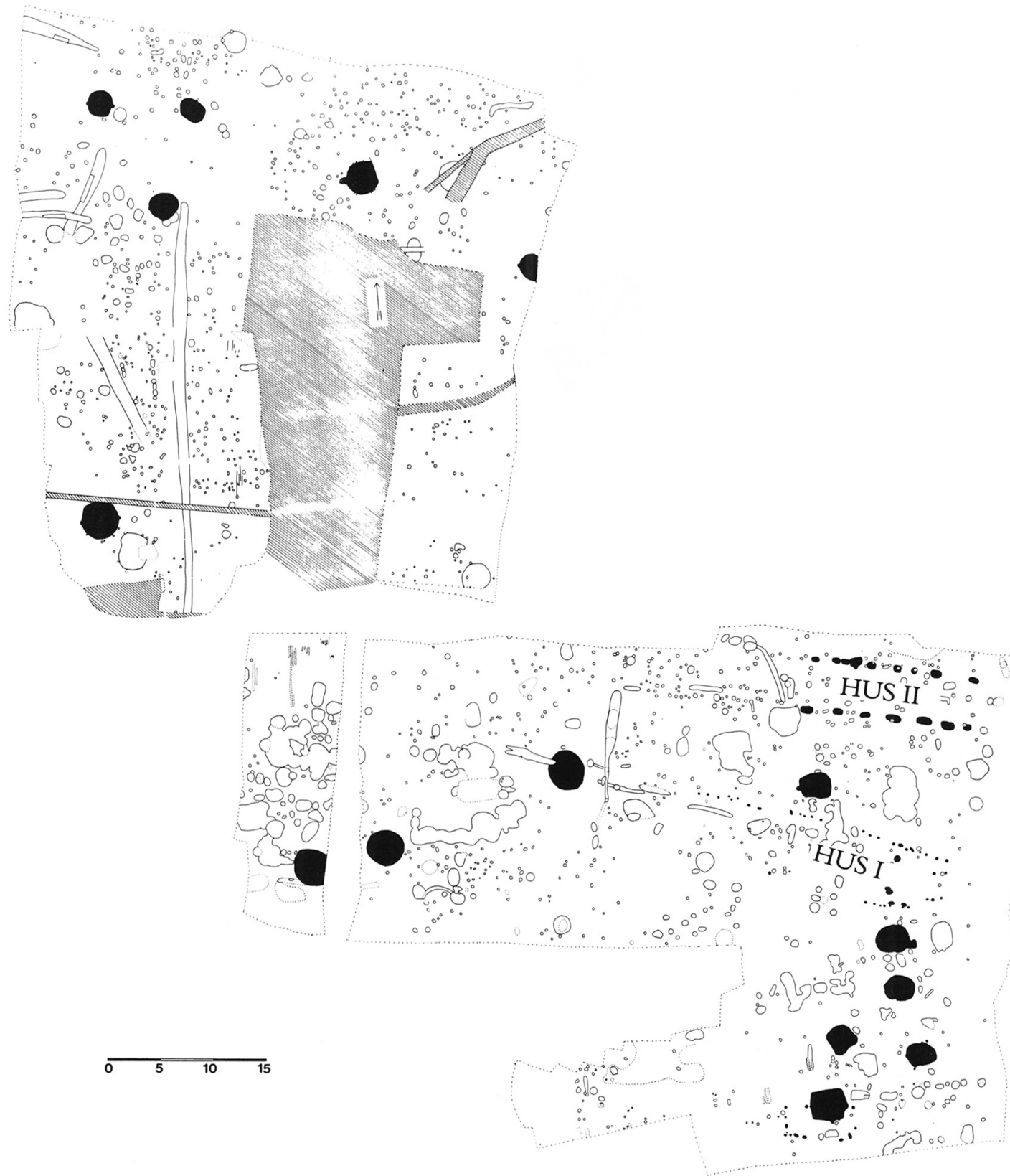

Fig. 3. Udgravningsfeltet ved Fur Kirkevej i den sydlige del af Nederby. Langhuse og grubehuse er fremhævet med sort. Skravering angiver moderne forstyrrelser. Tegning: Sonja Justesen.

Excavation area at Fur Kirkevej in the southern part of Nederby. Hatching indicates recent disturbances. 


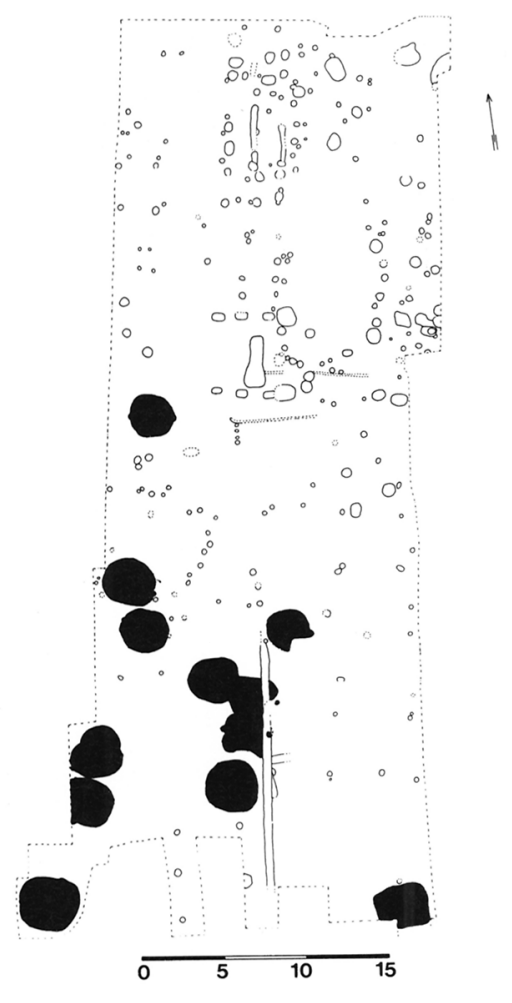

Fig. 4. Udgravningsfeltet på Bjerregårdsbakke i den nordlige del af Nederby. Grubehuse er fremhævet med sort. Tegning: Sonja Justesen.

Excavation area on Bjerregårdsbakke in the northern part of Nederby.

sjældent gravet mere end en halv meter ned i undergrunden. Foruden et tyndt, fedtet bundlag rummede husene ofte blot et enkelt opfyldningslag.

Som eksempel på udformningen af grubehusene skal vi i det følgende se nærmere på 3 grubehuse fra Bjerregårdsbakke (fig. 5). De 3 huse lå med indbyrdes skæringspunkter og har dermed stor betydning for vurderingen af keramikmaterialet.

Det nordligste grubehus (anlæg MO) er det ældste. Afstanden mellem husets to tagbærende stolper er 2,65 meter målt fra midten af stolperne. Huset var nedgravet $35 \mathrm{~cm}$ under afrømningsniveau. Foruden et bundlag rummede huset undtagelsesvis 3 opfyldningslag, hvoraf det midterste bestod af rent undergrundsgrus. Efter afrensning af det mellemste fyldlag sås i husets nordside 5 stolpehuller, der gik gennem de 2 nederste opfyldslag, men ikke i undergrund. Disse stolper må stamme fra en sekundær anvendelse af huset efter delvis opfyldning. Tilsvarende stolper kunne ikke ses i husets sydside, hvor der i undergrunden sås et hul efter en nedhamret vægpæl, der hører til husets primære anvendelsesperiode. Det sydøstlige hjørne af det ældste grubehus skæres af det syd for liggende hus (anlæg NB).

Dette hus måler 2,85 meter mellem de tagbærende stolper. Huset er nedgravet $10 \mathrm{~cm}$ under afrømningsniveau. Over bundlaget fandtes eet opfyldningslag. Østenden af dette grubehus skæres af en omtrent 1 meter bred nord-syd gående grøft (anlæg NE). Husets østlige tagbærende stolpe og en nedhamret vægpæl ses øst for grøften. Under afrømningen blev husets sydøstlige del noget afgravet, 


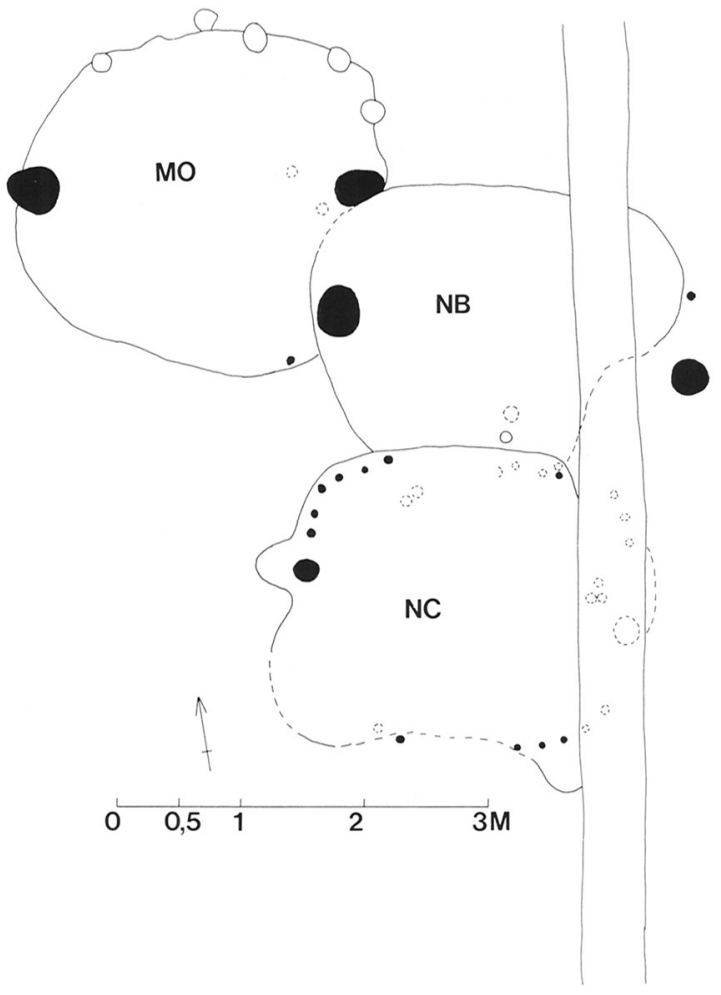

Fig. 5. På Bjerregårdsbakke lå de tre grubehuse $\mathrm{MO}, \mathrm{NB}$ og $\mathrm{NC}$ med indbyrdes skæringspunkter. Tegning: Sonja Justesen efter opmåling af Anne Petersen.

On Bjerregårdsbakke there were three intersecting pit huts, $\mathrm{MO}, \mathrm{NB}$, and $\mathrm{NC}$. Drawing: Sonja Justensen After survey by Anne Petersen.

dels på grund af husets ringe dybde og dels fordi de to ældste grubehuse begge var anlagt i groft undergrundsgrus. Sydsiden af det mellemste grubehus skæres af det yngste hus (anlæg NC). Dette hus er anlagt i undergrundssand, hvilket har givet gode iagttagelsesforhold. Huset måler 2,80 meter mellem de tagbærende stolper og har en velbevaret væglinie af tætstillede nedhamrede pæle, der står med en afstand på 30-40 cm. Et klart stolpespor sås, hvor den østlige tagbærende stolpe havde stået. Stolpen havde en diameter på $19 \mathrm{~cm}$ og har været stenstøttet ligesom veststolpen. Huset er nedgravet $5-10 \mathrm{~cm} \mathrm{i} \mathrm{undergrunden} \mathrm{og}$ rummer foruden bundlaget eet opfyldningslag. Også det yngste grubehus skæres af den nord-syd gående grøft, husets østlige tagbærende stolpe og en del vægpæle overlejres af grøften.

På Bjerregårdsbakke ses endnu et eksempel på stratigrafi, idet et grubehus (anlæg MA) består af 2 huse, hvor det ene er anlagt næsten direkte oven i det sløjfede. På Fur Kirkevej findes også kun få eksempler på skæringspunkter. Lige vest for de to langhuse (fig. 3) skæres et cirkulært grubehus af en nordvestsydøst gående grøft, der igen skæres af en nord-syd gående grøft. Den partielt bevarede nordvest-sydøst gående grøft kan ikke være samtidig med hus I.

Der er således spor efter 3-4 faser i bebyggelsen såvel på Bjerregårdsbakke som på Fur Kirkevej. Det er dog umuligt at udskille egentlige gårdsanlæg, da det ikke kan afgøres, hvilke anlæg der har været i brug samtidigt. 


\section{Datering og tolkning}

Det er et karakteristisk træk for huse fra ældre germansk jernalder, at det sidste sæt tagbærende stolper står i nogen afstand fra gavlene. Det er f.eks. tilfældet i 5.-7. århundredes husene i Nørre Snede (7). I yngre germansk jernalder rykker det sidste sæt tagbærende stolper ud i gavlene (8). Da det sidste sæt tagbærende stolper i hus I netop er placeret lige indenfor gavlen, kan det med rimelighed dateres til yngre germanertid. I et af husets stolpehuller fandtes randskåret af et halvkuglekar (fig. 9,2). Hus I kan derfor ikke være ældre end år 700, hvorfor en datering til 700-tallet, evt. begyndelsen af 800-tallet, må være sandsynlig.

Det enskibede langhus kendes efterhånden fra en række syd- og midtjyske lokaliteter, hvor det tilsyneladende er videreudviklet af Trelleborghuset (9). Først forsvinder de indre tagbærende stolper, dernæst de ydre, skrå støttestolper. Det enskibede langhus kendes fra såvel vikingetidens slutning (10), som den tidlige middelalder (11). Fra et af stolpehullerne til hus II fremkom et bugskår af blødtbrændt oldtidsgods. Hus II kan derfor bedst dateres til sidste halvdel af 1000-årene eller tiden omkring år 1100.

Grubehusenes alder kan belyses gennem tre C-14 dateringer. Et cirkulært grubehus på Bjerregårdsbakke (anlæg ND) er dateret til år 650-770 e. Kr. (12). Dette er i overensstemmelse med, at et tilsvarende hus fra Trabjerg er dateret til 700-tallet (13). Et rektangulært grubehus (anlæg AHR) fra Fur Kirkevej er C-14 dateret til 880-995 e. Kr. (14), og et cirkulært grubehus (anlæg ASG) fra Fur Kirkevej er C-14 dateret til 975-1035 e. Kr. (15).

C-14 dateringerne viser, at grubehusene i Nederby er anlagt gennem omtrent 300 år. Dette er i overensstemmelse med de stratigrafiske iagttagelser, der viser, at grubehusene har afløst hinanden, og at bebyggelsen som helhed strækker sig over 3 til 4 faser.

Ser vi på den totaludgravede Vorbasse landsby, er det karakteristisk, at de enkelte gårdsanlæg kun har haft et eller et par grubehuse i brug af gangen, idet der løbende er bygget nye huse til erstatning af de nedslidte (16). Herved opstår der klynger af grubehuse, der dog ikke har eksisteret samtidigt. I Nederby ser vi tilsvarende klynger af grubehuse, tydeligst på Bjerregårdsbakke, hvor de 13 grubehuse ligger indenfor et område på kun 20x30 meter (fig. 4). Også på Fur Kirkevej (fig. 3) er der en klar koncentration af grubehuse i udgravningsfeltets sydøstlige del.

Vender vi os igen mod Vorbasse, så består 8.-10. årh. landsbyen af 7 gårdsanlæg, der ligger omkring en midtergade. Grubehusene ligger her i området ud mod midtergaden, det vil sige i udkanten af gårdsanlæggene og i stor afstand fra gårdenes hovedbygninger (17). Det synes ikke urimeligt at overføre dette til Nederby, idet grubehusene her ikke alene ligger i klynger, men klyngerne ligger også tæet op af grøftsystemerne. Derfor kan det ringe antal langhuse i Nederby måske forklares med, at udgravningsfelterne ligger i udkanten af eller på overgangen mellem to eller flere gårdsanlæg (jvf. note 6). Hvis denne tolkning holder, ligger gårdenes hovedbygninger i området nord for udgravningsfeltet på Fur Kirkevej og i området øst for feltet på Bjerregårdsbakke, det vil sige under den nuværende bebyggelse (fig. 2).

Samlet må derfor siges, at Nederby ikke på nuværende tidspunkt kan bidrage med oplysninger om bebyggelsesstrukturen. Hertil er udgravningsfelterne for 
små. Det $5500 \mathrm{~m}^{2}$ store udgravningsareal i Nederby er dog overordentlig stort sammenlignet med de små dateringsgravninger, der normalt anvendes ved gravning i eksisterende landsbyer. I det fynske landsbyprojekt udgravedes f.eks. blot $71,7 \mathrm{~m}^{2} \mathrm{pr}$. landsby (18). Nederby-undersøgelserne kan dermed bidrage til vurdering af de små dateringsfelters anvendelighed sammenlignet med større fladegravninger. I den forbindelse skal allerede her nævnes, at det relativt store udgravningsareal i Nederby har været en absolut forudsætning for at tilvejebringe et rimeligt dateringsgrundlag. Herom senere.

\section{Keramik}

Det samlede keramikmateriale fra Nederby omfatter to tilnærmelsesvis hele kar og 409 skår, heraf 64 randskår (15,6\%). Keramikken fordeler sig med 253 skår på Fur Kirkevej, heraf 38 rande $(15,0 \%)$ og 156 skår på Bjerregårdsbakke, heraf 26 rande $(16,7 \%)$.

Da mængden af publiceret vikingetidskeramik fra det nordvestjydske område er yderst begrænset, skal et bredt udsnit af Nederby keramikken her fremlægges. Keramikken gennemgås anlæg for anlæg, dog med hovedvægten på de anlæg, der rummer kombinationer af flere kartyper eller anlæg, der ligger i stratigrafisk kontekst. Keramikken er generelt af blødtbrændt oldtidsgods, groft magret med ru overflade, der viser karrets pølseopbygning. Enkelte skår er dog hårdere brændte, uden dog at være af egentlig hårdtbrændt middelaldergods. Disse skår bliver i det følgende betegnet som mellembrændte.

\section{Bjerregårdsbakke}

Keramikgennemgangen kan passende tage sit udgangspunkt på Bjerregårdsbakke $\mathrm{i}$ de tre grubehuse, der lå med indbyrdes skæringspunkter. Fra bundlaget $\mathrm{i}$ det ældste grubehus (anlæg MO) fremkom overdelen af et velforarbejdet kar (fig. 6,1). Karrets nøjagtige form er svær at bestemme, da både rand og bund mangler. Der må dog være tale om et bredbuget, svajet eller treleddet kar. I opfyldningslaget over et af grubehusets stolpehuller - det vil sige fra husets nedlæggelse - fremkom siden af et rundbundet halvkuglekar med svagt indadbøjet rand (fig. 6,2). Fra bundlaget i det efterfølgende grubehus (anlæg NB) stammer et næsten helt lerkar (fig. 6,3). Det er et lille, blot $10 \mathrm{~cm}$ højt rundbundet bæger med lodrette sider og svagt indadbøjet rand. I husets opfyldningslag fandtes et lille randskår af et halvkuglekar (fig. 6,4).

I opfyldningslaget til det yngste grubehus (anlæg NC) fremkom randskåret af endnu et halvkuglekar (fig. 6,5) og et stempelornamenteret randskår (fig. 6,6). Det stempelornamenterede skår har let fortykket, svagt udfaldende rand og en kraftig markeret overgang til bugen. Lige under randen ses to rækker af modsatstillede, skraverede trekantstempler. Stempelornamenterede kar af denne type dateres generelt til yngre germansk jernalder (19).

De tre grubehuse fra Bjerregårdsbakke dækker dermed 700-tallet og formentlig også dele af 600 årene, da det bredbugede kar med udfaldende rand fra det ældste grubehus har træk tilfælles med keramik fra overgangen mellem xldre og yngre germansk jernalder (20).

Fra bundlaget i et andet grubehus (anlæg NR) ser vi et halvkuglekar med svagt indadbøjet rand (fig. 7,1). I husets opfyldningslag fandtes endnu et halv- 

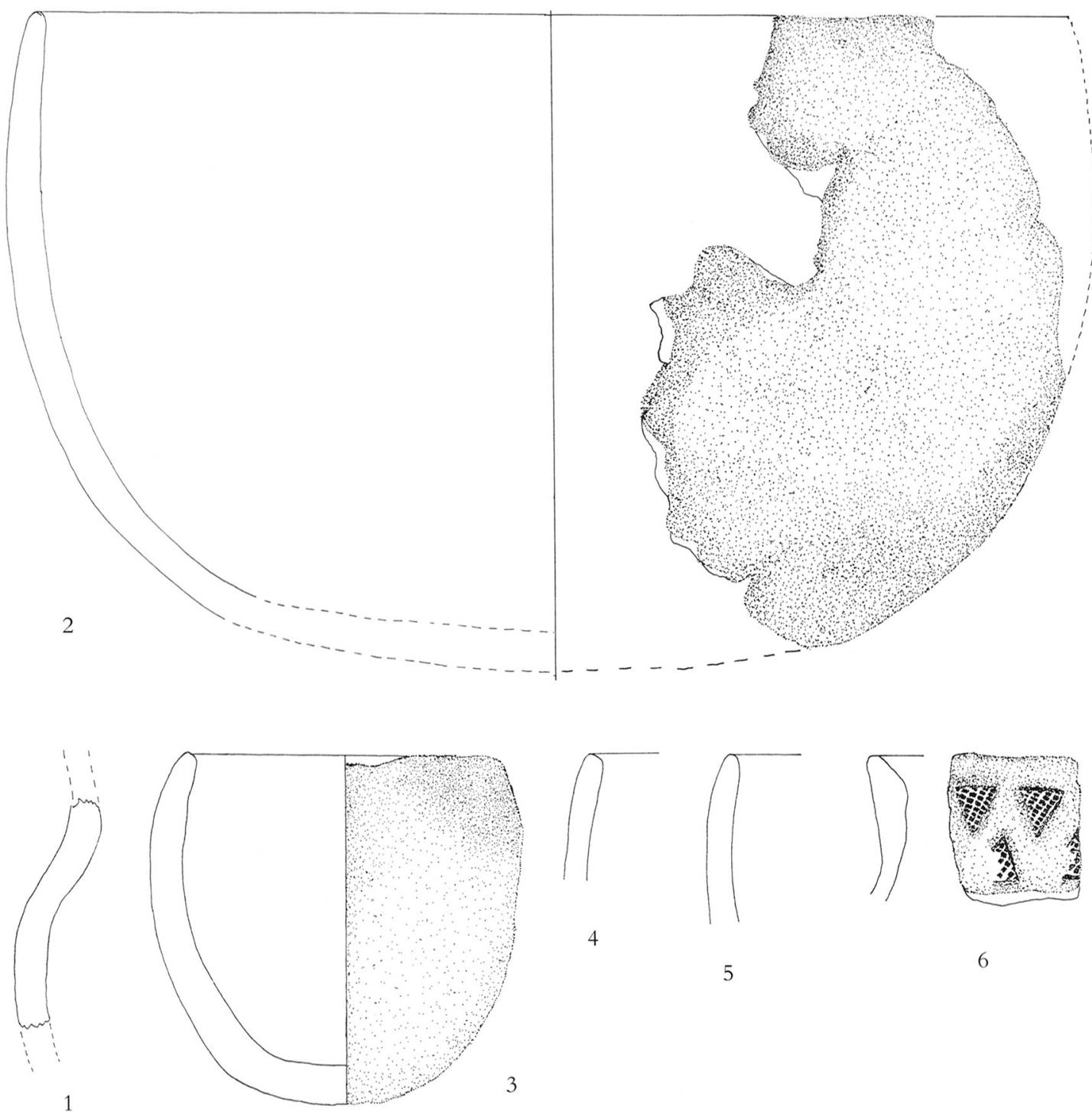

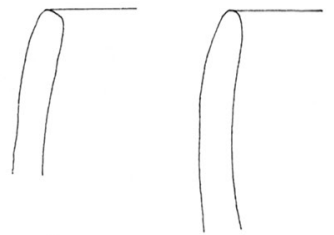

4
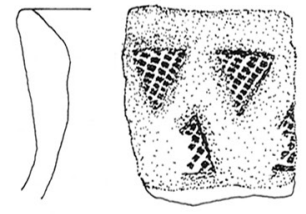

5

6

Fig. 6. Keramik fra de tre stratigrafiske grubehuse på Bjerregårdsbakke. 1:2. 6,1-6,2 stammer fra det ældste grubehus, henholdsvis bund- og opfyldningslag. 6,3-6,4 stammer fra det mellemste grubehus og 6,5-6,6 fra det yngste hus. Tegning: Margrethe Larsen.

Pottery from the three strategraphic pit huts on Bjerregårdsbakke. 6,1-6,2 is from the older pit hut, bottom and fill slag respectively. $6,3-6,4$ is from the middle pit hut and 6,5-6,6 is from the younger pit hut.

kuglekar (fig. 7,2). Et halvkuglekar med jævnt indadbøjet rand (fig. 7,3) og et halvkuglekar med stærkt indfaldende rand (fig. 7,4) stammer begge fra opfyldningslaget i det til år 650-770 e. Kr. C-14 daterede grubehus (anlæg ND). Hertil kommer en række anlæg med blot et enkelt halvkuglekar. Disse anlæg kan ikke dateres nærmere indenfor halvkuglekarrets levetid. At der er tale om en meget lang levetid, understreges af fundene fra to andre grubehuse. Fra det 


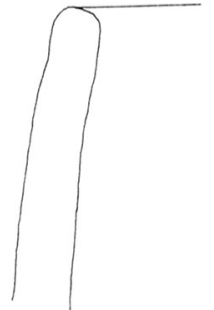

1
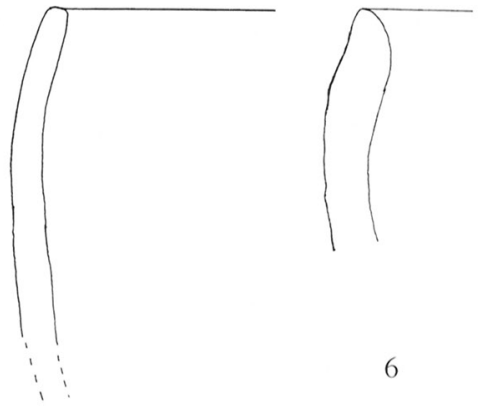

6
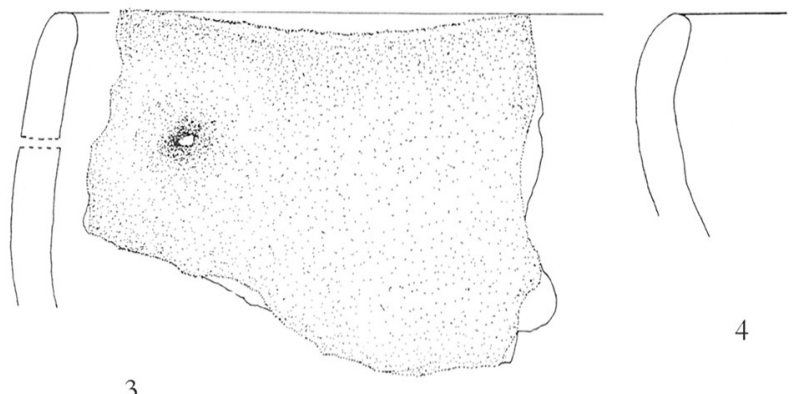

4

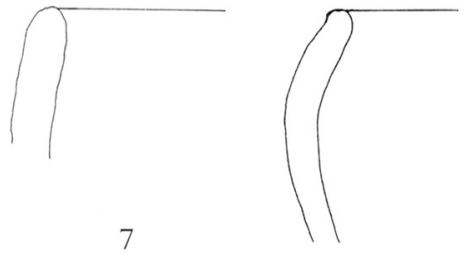

8

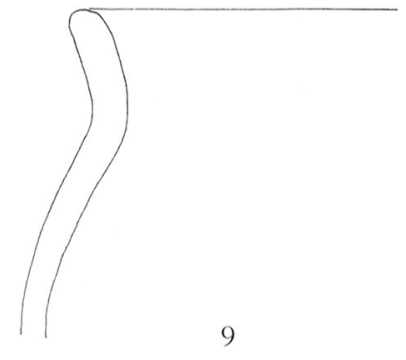

5

Fig. 7. Keramik fra Bjerregårdsbakke. 1:2. Tegning: Margrethe Larsen.

Pottery from Bjerregårdsbakke.

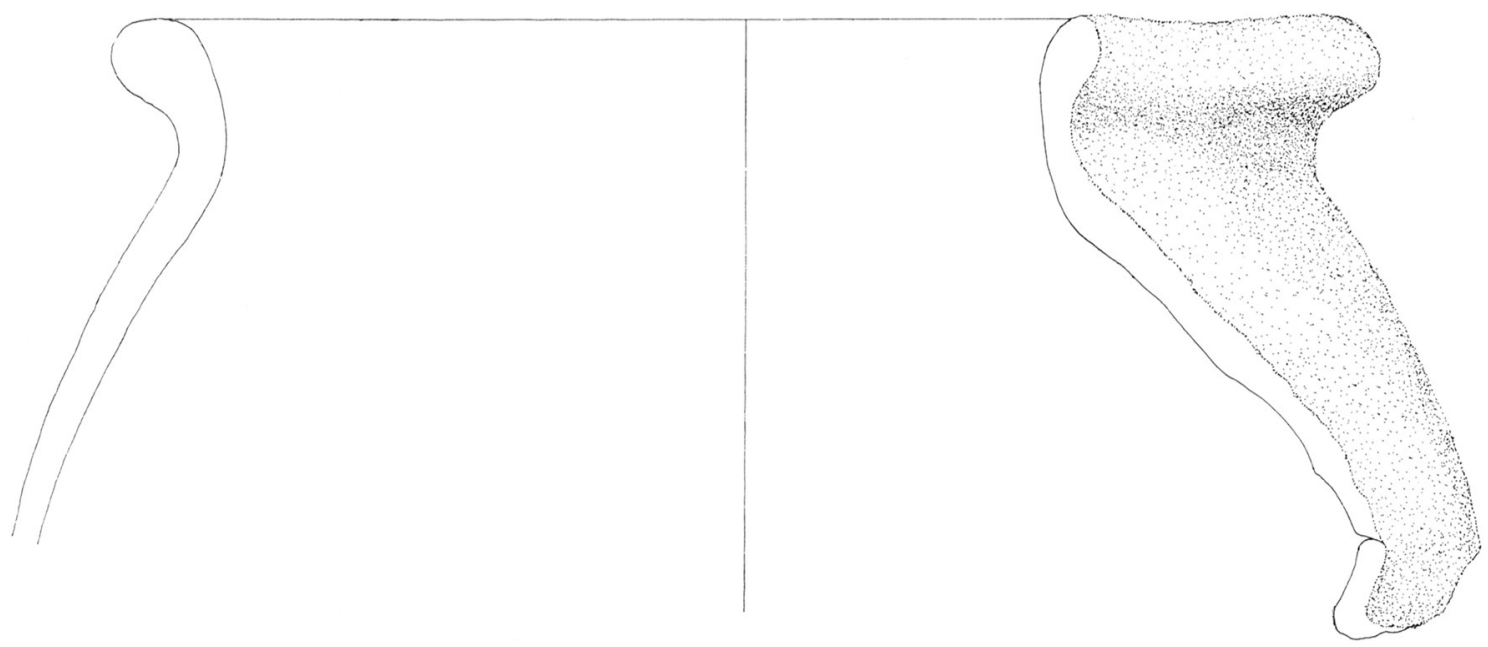

Fig. 8. Randskår af kuglepotte fundet på Bjerregårdsbakke 6. Tegning: Margrethe Larsen.

Rim sherd of spherical pot found at Bjerregårdsbakke 6. 
eneste rektangulære grubehus på Bjerregårdsbakke (anlæg AO) stammer to randskår. Det ene (fig. 7,5) har svagt indadbøjet, næsten lodretstillet rand. Det andet (fig. 7,6) har kraftigt indfaldende rand, der er let fortykket, optrukken og med indvendig facet. Sidstnævnte skår er af mellembrændt gods. Begge skår er fundet i husets opfyldningslag, det vil sige fra nedlæggelsen af det rektangulære grubehus. I et andet grubehus (anlæg LD) fandtes tre randskår i bundlaget, nemlig et halvkuglekar med jævnt indadbøjet rand (fig. 7,7), et tyndvægget halvkuglekar med stærkt indfaldende rand (fig. 7,8) og endelig et kuglepottelignende randskår med let udfaldende rand (fig. 7,9). De to sidstnævnte skår er af mellembrændt gods. På grund af tilstedeværelsen af den hårdere brændte keramik i de to sidstnævnte grubehuse, må disse sandsynligvis dateres sent. (21).

Regulær tidlig middelalderkeramik er også fundet på Bjerregårdsbakke, dog ikke i udgravningsfeltet, men omtrent 40 meter sydøst for dette. Ved byggeri på Bjerregårdsbakke 6 fandtes overdelen af en kuglepotte (fig. 8).

\section{Fur Kirkevej}

Vender vi os mod keramikken fra Fur Kirkevej, ser vi de samme kartyper som på Bjerregårdsbakke. Vi har igen et stempelornamenteret skår fra yngre germansk jernalder (fig. 9,1). Skåret, der fremkom i en grube (anlæg BOF), omfat-
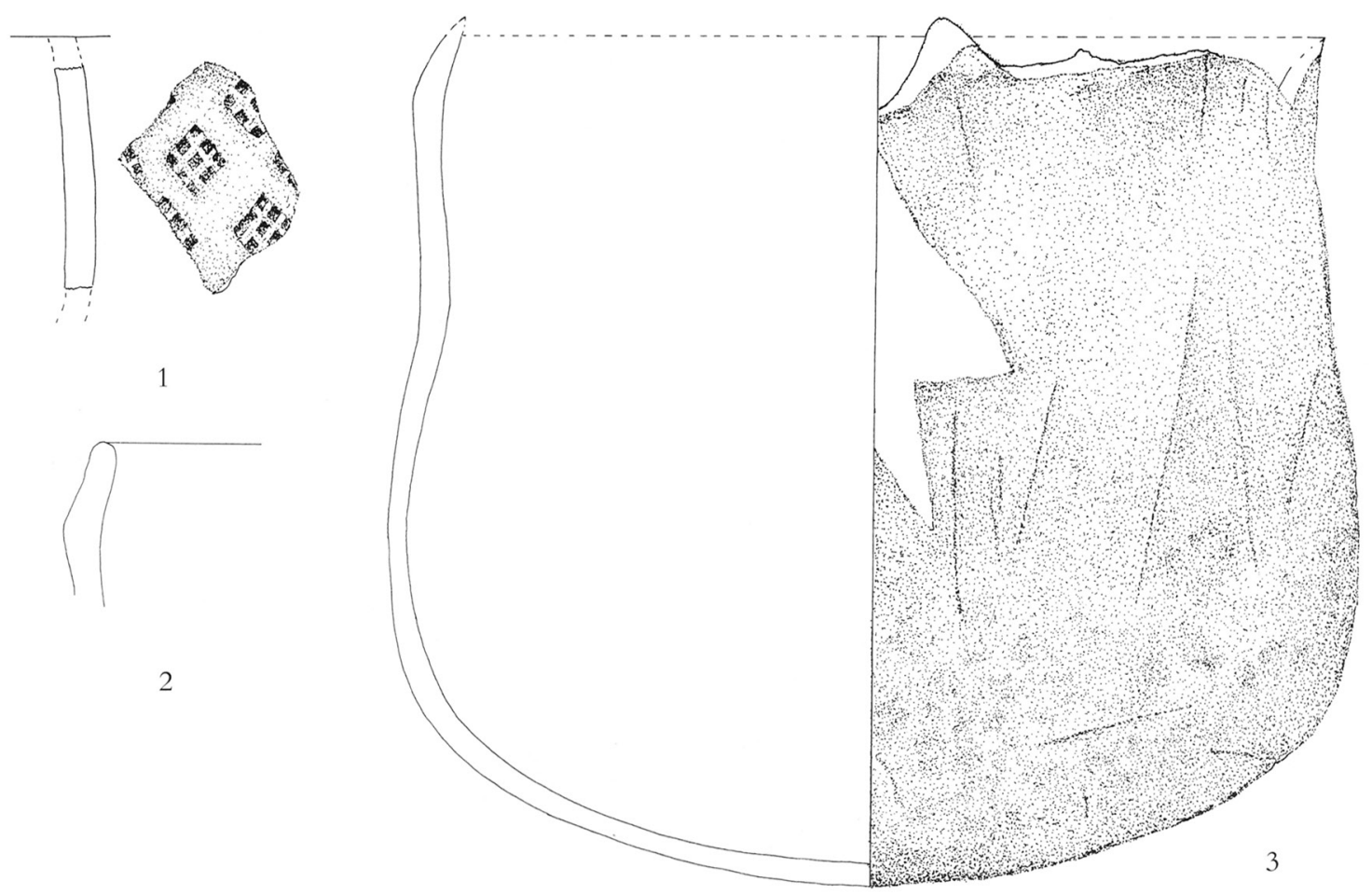

Fig. 9. Keramik fra Fur Kirkevej. 1:2. Tegning Margrethe Larsen.

Pottery from Fur Kirkevej. 

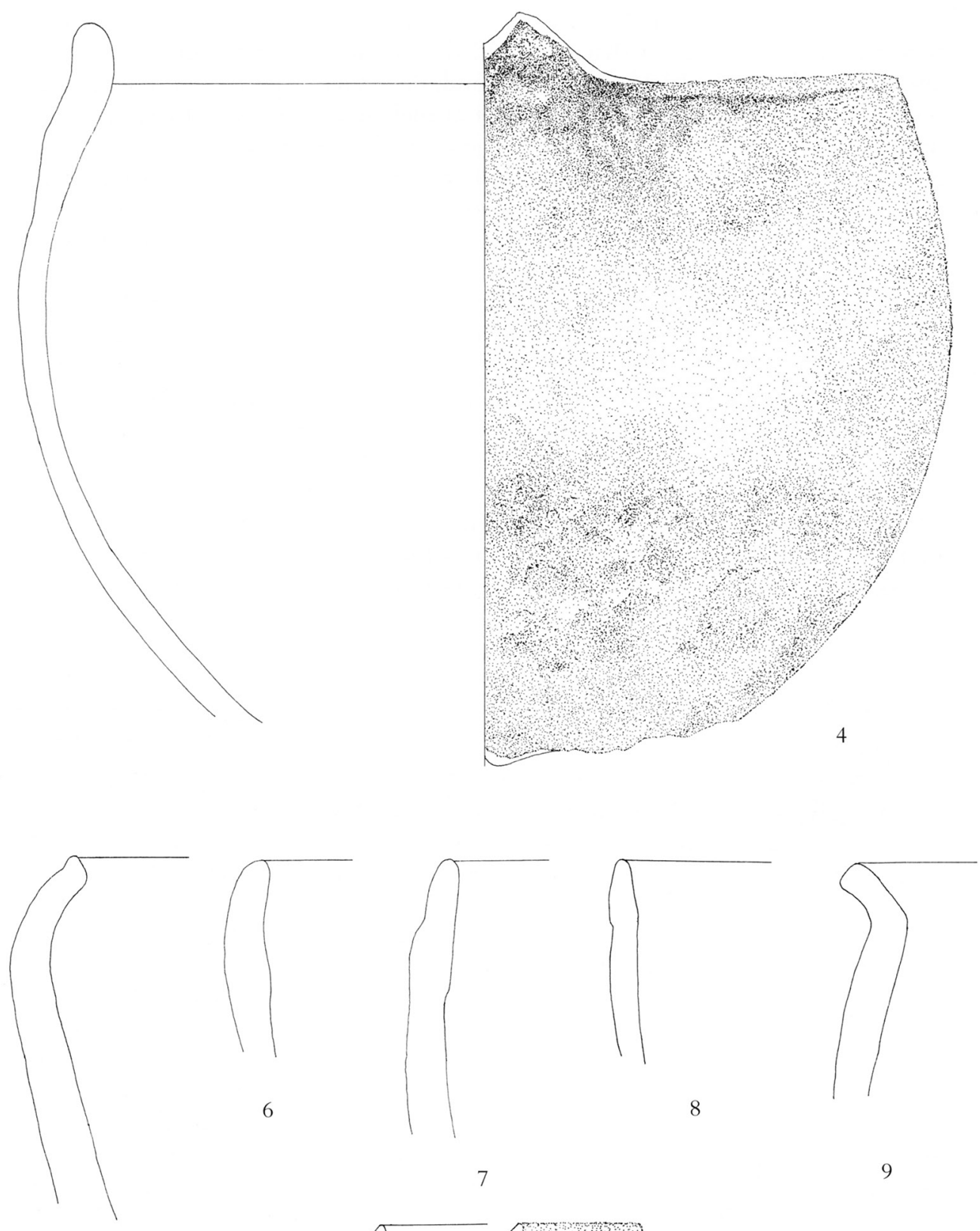

5

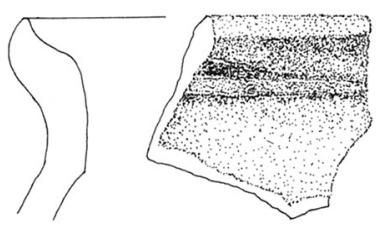

10

Fig. 9. 1:2. 
ter overdelen af bugen med overgang til halsen. Der er bevaret dele af syv rudestempler, der har siddet i tre vandrette, omløbende bånd på bugens overdel. Stemplerne står på spidsen som rhomber og er krydsskraverede, så hvert stempel er delt i ni små ruder. Stempelornamentikken formodes at have været fladedækkende.

I modsætning til Bjerregårdsbakke har anlæggene på Fur Kirkevej som oftest kun givet et enkelt randskår af halvkuglekar. Det gælder eksempelvis stolpehullerne til hus I, hvorfra blot kom et enkelt randskår af halvkuglekar med svagt indadbøjet rand (fig. 9,2). Et formodet svaleredekar (fig. 9,3) fremkom i en lille grube og et klart svaleredekar (fig. 9,4) fandtes i et grubehus (anlæg ANX). En grube (anlæg AG) rummede dog randskår af to halvkuglekar med stærkt indfaldende rand (fig. 9,5-6) af mellembrændt gods. Fra bundlaget $i$ et grubehus (anlæg $\mathrm{BOH}$ ) fandtes et regulært halvkuglekar (fig. 9,7) og i fyldlaget et skår med omtrent lodretstillet rand og udvendig facet (fig. 9,8). Godset er mellembrændt, fint magret og med glat overflade, dog ikke glittet.

Den hårdtbrændte tidlige middelalderlige keramik er også repræsenteret på Fur Kirkevej, eksempelvis i form af en kuglepotte (fig. 9,9) fra en grube (anlæg $\mathrm{AD})$, og i form af et randskår med lågfals (fig. 9,10) fra endnu en grube (anlæg APS).

\section{Datering og sammenfatning}

Samlet må siges, at keramikken fra såvel Fur Kirkevej som Bjerregårdsbakke dækker tidsrummet fra yngre germansk jernalder til tidlig middelalder. Dette støttes af de tre førnævnte C-14 dateringer, hvoraf den ene er fra yngre germanertid og de to øvrige fra vikingetiden. Hertil kommer en fjerde C-14 datering af den nedenfor nævinte slaggegrube fra 1045-1225 e. Kr. (22). Dette stemmer overens med, at de to langhuse ud fra konstruktive træk lader sig datere til 700og 1000-tallet.

I keramikken lader yngre germanertidsmaterialet sig let udskille på grund af de 2 skår med formodet fladedækkende stempelornamentik og ikke mindst de 3 stratigrafiske grubehuse med et treleddet eller svajet kar i det ældste hus. Ligeledes er det sene vikingetidsmateriale let erkendeligt på grund af den hårdere brænding, og det samme gælder naturligvis den egentlig hårdtbrændte tidlig middelalderlige keramik med kuglepotter og rande med lågfals. Det forhold, at vikingetidskeramikken - bortset fra 2 svaleredekar - udelukkende består af halvkuglekar, rejser imidlertid en række spørgsmål. Ganske vist optræder der i Nederby såvel halvkuglekar med svagt indbøjede, næsten lodretstillede rande som kar med stærkt indfaldne rande - men antallet af kombinationsfund er så beskedent, at det ikke giver grundlag for at pege på tidlige eller sene træk i keramikudviklingen indenfor halvkuglekarrets lange levetid fra omkring år 700 til tiden omkring år 1000. Karkombinationerne antyder blot, at der måske sker en relativ stigning i antallet af stærkt indfaldne rande. Der kan ikke peges på findaterede enkeltelementer. Med vor nuværende viden om keramik kan det derfor ikke afgøres, om de to udgravningsfelter på Fur Kirkevej og Bjerregårdsbakke begge har absolut kontinuitet eller hvor længe de to bebyggelser har eksisteret samtidigt. 
De dateringsmæssige problemer understreges, når man ser på antallet af randskår i forhold til udgravningsfelternes størrelse. I Nederby er der fundet 1 randskår pr. $86 \mathrm{~m}^{2}$. I det fynske landsbyprojekt udlagdes et beskedent antal dateringsfelter på tilsammen knap $72 \mathrm{~m}^{2}$ pr landsby. Det må være indlysende, at denne fremgangsmåde ville have givet et yderst tilfældigt dateringsgrundlag, hvis den var praktiseret i Nederby. Det rejser spørgsmålet, om man har et reelt dateringsgrundlag, når man står med nogle fă skår af halvkuglekar fra en mindre gravning i en eksisterende landsby. Vil man da ikke skele til det generelle kontinuitetsbrud på overgangen mellem vikingetid og tidlig middelalder og dermed a priori datere sådanne skår til sen vikingetid?

\section{Ovrige fund}

Ved udgravningerne i Nederby er der fremkommet omkring $50 \mathrm{~kg}$ jernslagger. Der er hermed tale om den hidtil største slaggemængde fra en dansk vikingetidslandsby (23). Slaggen stammer fra 19 anlæg, ofte grubehuse med 1-4 kalotformede slagger i bund- eller opfyldningslaget. To gruber (anlæg AWS og AWR) påkalder sig dog særlig interesse, dels på grund af den store slaggemængde $-16 \mathrm{~kg}$ i hver grube - dels på grund af grubernes formodede funktion og samtidighed. Anlæg AWS er en 100x120 cm stor omtrent cirkulær grube. Gruben var nedgravet $32 \mathrm{~cm}$ i undergrunden og havde jævnt afrundede sider. Grubens vest- nord- og østlige kanter bestod af stærkt porøse, lette slagger, der sad indsmeltet i undergrundsleret. Slaggerne sås ikke i grubens sydlige kant. På bunden af gruben fandtes en enkelt stor, tung jernslagge, der lå med den glatte side opad og den blærede side nedad. I grubens meget trækulholdige fyld fandtes rødbrændte lernister, enkelte stykker lerklining, såvel lette slagger som tunge kalotformede slagger og endelig en vinkelformet esseslagge. Den vinkelformede esseslagge kendes blandt andet fra Ribe (24) og består af en slaggekage, der er dannet på indersiden af en avlssten. Øverst i slaggekagen ses hullet til blæsebælgens tud, derfra er slaggen løbet ned af avlsstenens inderside og derpå vandret ud på grubens bund. Den vinkelformede esseslagge viser, at der må være tale om en essegrube. Dette understreges af kemiske analyser af slaggematerialet, idet den lette, porøse slagge i grubens kanter er ler, formentlig undergrundsleret, der er sintret på grund af den høje temperatur i essen (25). Da denne lerslagge mangler i grubens sydlige kant, kan det antages, at avlsstenen har været placeret netop her. Den meget trækulholdige fyld har som tidligere nævnt givet en C-14 datering på 1045-1225 e. Kr.

I blot 2 meters afstand fra denne essegrube lå den anden grube med $16 \mathrm{~kg}$ slagger (anlæg AWR). Denne grube var 110x140 cm stor og $130 \mathrm{~cm}$ dyb. Såvel de lette lerslagger som de kalotformede slagger lå spredt i grubens fyld, dog hovedsagelig i de øverste opfyldningslag. Der kunne ikke konstateres indsmeltede, sintrede lerslagger i grubens sider eller nogen vinkelformet esseslagge. Samtidig var trækulsmængden så beskeden, at der ikke har været ild i gruben. Der blev fundet fire små sideskår af hårdtbrændt gods i fylden. AWR kan derfor være samtidig med essegruben AWS. Dette understreges tillige af, at slaggematerialet fra de to anlæg er identisk.

Umiddelbart omkring disse to anlæg fandtes yderligere to små gruber (anlæg AWN og AVN) med henholdsvis 1,5 og 1,9 kg slagger. Om disse to gruber er 
samtidige med de to førnævnte, kan ikke afgøres med sikkerhed, men det forekommer sandsynligt på grund af grubernes samlede placering, der adskiller sig fra de øvrige spredte slaggefund. Det samlede indtryk er, at vi her står overfor en sikker essegrube med 1-3 funktionsgruber, hvis nærmere anvendelse ikke lader sig bestemme. Fundet viser, at smedehåndværket har været tilstede i Nederbybebyggelsen i 1100-årene eller begyndelsen af 1200-årene at dømme efter både C-14 datering og keramik. Der har dog også været smedeaktivitet tidligere i bebyggelsen. Dette understreges tydeligst af, at der blev fundet en kalotformet slagge i gruben med det stempelornamenterede yngre germanertidsskår (fig. 9,1).

Bortset fra slaggerne er fundmaterialet af beskeden karakter: et par drejekværne, nogle få knogler af hest og svin, lidt forkullet korn, vævevægte fra omkring en fjerdedel af grubehusene og nogle fă forarbejdede metalgenstande, hvoraf størsteparten endog stammer fra et enkelt grubehus. Det sparsomme, ja, næsten fattige fundmateriale understreges af, at de ellers så typiske handelsvarer som rav- og glasperler eller klæbersten og skiferhvæssesten mangler fuldstændigt, bortset fra en enkelt glasperle. To ubestemmelige bronzegenstande må være tilført udefra. Selv om råjern eventuelt også kan være tilført, afspejler fundene ikke nogen større handelsaktiviteter ud over den lokale handel.

\section{Bebyggelse og erhverv i Limfjordsområdet}

Fra den vestlige del af Limfjorden kendte vi indtil 199025 bebyggelser fra yngre germansk jernalder og/eller vikingetid (fig. 1 og fundliste). Næsten halvdelen af disse bebyggelser er regulære kystbebyggelser. Fjorden har derfor været en afgørende faktor for områdets bebyggelse.

Fund af klæbersten, importeret fra Norge og Sverige, afspejler fjordens betydning som handelsvej. Der er ofte tale om lokal handel, men et par lokaliteter har så rige fund, at der kan være tale om handelspladser. Danmarks hidtil største fund af klæbersten, $25 \mathrm{~kg}$ i alt, stammer fra den civile bebyggelse og borgen ved Aggersborg (26). Aggersborg ligger strategisk velplaceret mellem indsejlingen til Limfjordens snævre østlige del og indsejlingen til en formodet sejlbar rende gennem Vendsyssel med udløb i Jammerbugten (27). I betragtning af, at der er udgravet mange tusinde kvadratmeter ved Aggersborg, er landets relativt set største fund af klæbersten formentlig fra Nørregård ved Jannerup i Thy. Her er der i et blot $100 \mathrm{~m}^{2}$ stort udgravningsfelt fundet $7-8 \mathrm{~kg}$ klæberstensskår (28). Nørregård ligger ligeledes strategisk velplaceret mellem to store søer, Sperring Sø og Sjørring Sø.

Sammenlignet med Aggersborg og Nørregård har Limfjordsområdets kystbebyggelse så fă handelsindikatorer, at de ikke kan betegnes som egentlige handelspladser. Det vil derfor være mest nærliggende at pege på fiskeriet som en betydelig faktor for disse kystbebyggelser.

Dette synes dog ikke at være $\mathrm{i}$ overensstemmelse med, at vi i Nederby kun kan spore to erhverv: landbrug og smedehåndværk.

Ser vi imidlertid på erhvervsmønstret på Fur i nyere tid, så er det karakteristisk, at så godt som alle gårde på øen drev dobbelterhvervet, landbrug og fiskeri (29). Det er typisk for det ikke motoriserede fiskeri før år 1900, at fiskeriet udgik fra en række landingspladser. En af disse lå på strandengen øst for Nederby. De 
øvrige lå forskellige steder langs øens kyst (30). Til disse landingspladser knyttede sig alle de aktiviteter, der var forbundet med fiskeri. Her landede bådene, fangsten blev solgt til fiskeopkøbere, ligesom både og garn blev vedligeholdt.

Disse aktiviteter efterlader kun ganske fă synlige spor. En landingsplads ved Morisvig på Vestfur har givet sig til kende ved en dynge sænkesten, fundamentet til en gruekedel til opvarmning af tjære og endelig en række firkantede trækasser, der var nedgravet i strandengen. Bådenes master blev stukket i trækasserne og anvendt til tørring af garn (31). Landingspladsen ved Morisvig var i brug indtil begyndelsen af dette århundrede. Nogle fă hundrede meter vest herfor ligger Furs vestligste punkt, den stejle morænebakke, Lille Knudshoved. Mod øst er morænebakken adskilt fra strandengene af et smalt, fladt plateau, der ligger ca. 1 meter over strandengene. Hvor dette plateau gennemskæres af den nuværende kystlinie, fremkom i 1984 et overraskende fund, nemlig en 900-tals stigbøjle (fig. 10). Stigbøjlen lå i et kulturlag og var overlejet af $50 \mathrm{~cm}$ sandblandet muld uden spor af nedgravning. Der er siden fundet gruber og blødtbrændt keramik i samme niveau, så der er ikke tale om et tilfældigt løsfund. Den aktivitet, der må være foregået på lokaliteten, har næppe været landbrug, hvilket synes umuligt på grund af områdets topografi. Det mest sandsynlige er derfor, at vi står overfor en landingsplads fra vikingetiden.

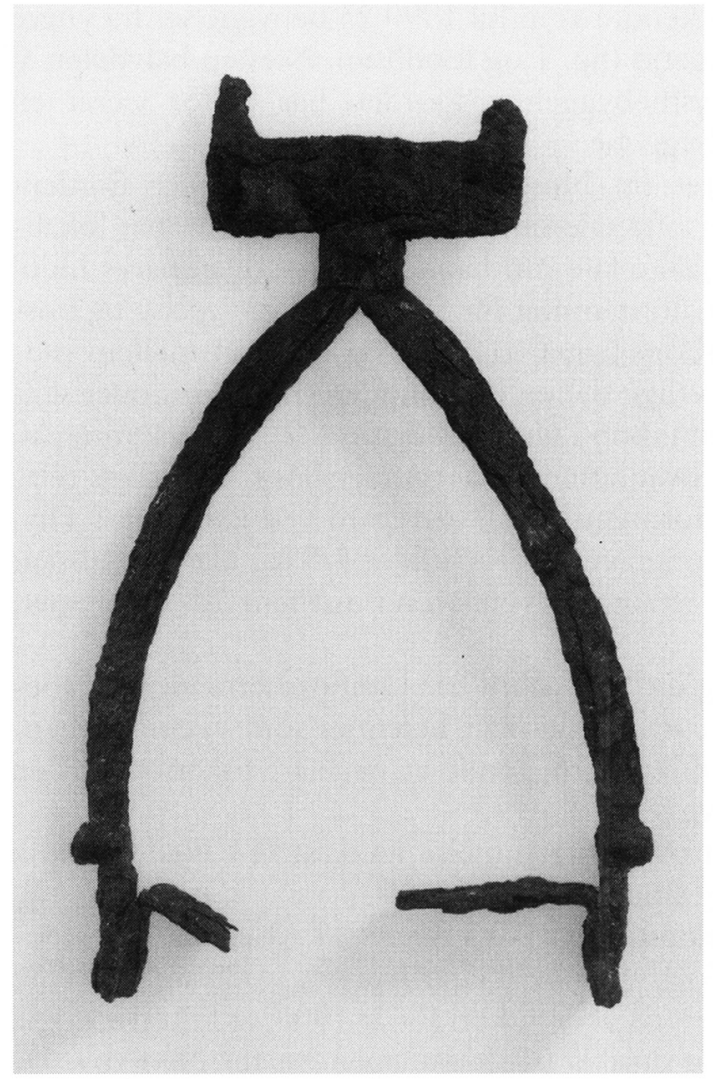

Fig.10. Stigbøjlen fra Lille Knudshoved. 1:2. Foto: Preben Dehlholm.

Stirrup from Lille Knudshoved. 
Hvis fiskeriet har været en væsentlig indtægstkilde allerede i vikingetiden, står vi overfor det problem, at den egentlige bebyggelse næppe vil afspejle dette, fordi fiskeriet er foregået fra landingspladser. Fiskeriet kan derfor være stærkt medvirkende til, at vi allerede omkring år 700 e. Kr. făr grundlagt Nederbybebyggelsen.

\section{Sammenfatning}

Den $5500 \mathrm{~m}^{2}$ store udgravning i Nederby er den hidtil største udgravning af nogen kystbebyggelse fra Limfjordsområdet, bortset fra Aggersborg. Udgravningsresultaterne er derfor værdifulde for det fremtidige arbejde i området. To forhold påkalder sig særlig opmærksomhed, fordi de giver indtryk af det arkæologiske materiales begrænsninger.

Mængden af keramik kan være så beskeden, at der kræves meget store udgravninger for at få et tilfredsstillende dateringsgrundlag. Ved størsteparten af de hidtil påviste vikingetidsbebyggelser i Limfjordsområdet er udgravningsarealet så beskedent, at det næppe er muligt at give en korrekt vurdering af, hvornår disse bebyggelser grundlægges og ophører. På grund af det beskedne undersøgelsesniveau kan vi heller ikke bedømme de enkelte bebyggelsers størrelse og struktur. Man bør derfor - selv ved gravning i eksisterende landsbyer - foretrække egentlige fladegravninger fremfor små dateringsfelter.

For det andet har fundene fra Nederby og Lille Knudshoved antydet, at det arkæologiske kildemateriale formentlig svigter, når vi skal vurdere fiskeriets erhvervsmæssige betydning, fordi fiskeriet allerede i vikingetiden kan være foregået fra landingspladser og ikke fra den egentlige agrare bebyggelse. Hvis fiskeriet allerede dengang var en væsentlig økonomisk faktor, kan det ikke udelukkes, at det kan give sig udslag i en bebyggelsesstruktur eller - kontinuitet, der afviger fra andre egne af landet.

Vor nuværende viden om vikingetidens bebyggelse bygger især på de stort anlagte undersøgelser af de midt- og vestjyske agrarbebyggelser og de frisisk påvirkede marskbebyggelser i Ribeområdet. De mange kystbebyggelser fra Limfjordsområdet er derfor et værdifuldt supplement hertil. Det nuværende undersøgelsesniveau giver ikke grundlag for vidtrækkende konklusioner, men antyder dog, at fiskeri og skudehandel var afgørende for Limfjordens bebyggelse allerede i vikingetiden.

\section{NOTER}

1) C.F. Becker: Viking-Age Settlements in Western and Central Jutland. Recent Excavations. Acta. Arch. Vol. 50, 1979.

2) T.G. Jeppesen: Middelalderlandsbyens opståen. Kontinuitet og brud i den fynske agrarbebyggelse mellem yngre jernalder og tidlig middelalder. 1981

3) Arkæologiske udgravninger i Danmark 1985. Nr. 246, 252, 256, 266a og 266b.

4) I undersøgelserne deltog cand. phil. Jytte Nielsen, cand. mag. Anne Petersen og cand. mag. Kirsten Christensen. Desuden Peter M.D. Jensen og Ketty Dahl. Undersøgelserne begyndte som en forskningsgravning i 1987 for midler fra Dronning Margrethe II Arkæologiske Fond. Undersøgelserne måtte dog hurtigt udvides med to redningsgravninger $i$ henhold til Museumslovens paragraf 26 forud for opforelsen af almennyttige boliger og et nyt ældrecenter. Udgifterne hertil blev dækket af henholdsvis Rigsantikvarens Arkæologiske Sekretariat og Sundsøre Kommune. At udgravningerne fandt sted over tre år skyldes, at de indgik som en integreret del af de forskellige byggeetaper. At dette kunne gennemføres uden forsinkelse af anlægsarbejdet skyldes et velfungerende samarbejde, der var koordineret af kommunearkitekt Børge Andreasen. Som administrativ leder fungerede museumsinspektør John Simonsen, Skive Museum. Som 
daglig leder af gravningerne vil forfatteren hermed takke samtlige implicerede - ikke mindst de Furboere, der har haft gravningerne på allernærmeste hold. Yderligere oplysninger om undersøgelsernes baggrund, se J.B. Berthelsen: Endnu et par brikker i et stort puslespil. MIV 15. 1989. p. 125-139, og J.B. Berthelsen: En regionalundersøgelse af bebyggelsesudviklingen på Fur. MIV 14. 1986. p. 18-44.5).

5) Danmarks Riges Breve 1975, 1. række, 11 bind, nr 172. I et diplom, der formentlig er fra 1166, bekræfter Bisp Niels, at hans forgænger, Bisp Eskild, for mere end 40 år siden fik overdraget Sct. Mortens Kirke på Fur, overdragelsen skete under samtykke af præsten Bo og kirkens grundlæggere: Guthi, Agi og Atti.

6) Bortset fra området omkring hus I var udgravningsfelterne dækket af et 60-120 cm tykt muldlag. Nyere tids pløjning kan derfor ikke have fjernet sporene efter evt. langhuse. Bent Aaby, Nationalmuseets VIII afdeling, har udtaget en række jordprøver, der er under analyse for at klarlægge gødskningens evt. betydning for den kraftige mulddannelse.

7) Arkæologiske udgravninger i Danmark 1986. p. 114, nr. 281.

8) U. Näsman: Huse, landsby, bebyggelse. Danmarks længste udgravning. 1987. p. 78f.

9) S. Jensen: Gårde fra vikingetiden ved Gl. Hvidding og Vilslev. Mark og Montre. 1986-87. p.21f.

10) S. Hvass: Se note 1, p. 156, fig. 17.

11) Arkæologiske udgravninger i Danmark 1985, p.131.nr. 356.

12) K-5431. Den angivne datering er omregnet til kalenderår og korrigeret for C-13. Konventionel datering $i$ C-14 år er 630 e. Kr. Prøven er lavet på trækul/grene med forholdsvis lav egenalder.

13) L.B. Jørgensen m. fl. se note 1, p. 135.

14) K-5363. Den angivne datering er omregnet til kalenderår og korrigeret for $C-13$. Konventionel datering $i$ C-14 år er $840 \mathrm{e}$. Kr. Prøven er lavet på mollusker med lav egenalder.

15) K-5340. Den angivne datering er omregnet til kalenderår og korrigeret for C-13. Konventionel datering $i$ C-14 år er 940 e. Kr. Prøven er lavet på hesteknogler med lav egenalder.

16) S. Hvass: Se note 1. p. 148.

17) Arkæologiske udgravninger i Danmark 1985, nr. 355.

18) T.G. Jeppesen: Anforte værk, p. 82.

19) Danmarks længste udgravning 1987, p. 248f, nr. 785.

20) S. Jensen: Grubehuset fra Darum, KUML 1985.

21) Jens Jeppesen og H.J. Madsen: Stormandsgård og kirke i Lisbjerg. KUML 1989, p. 299.

22) K-5500. Den angivne datering er omregnet til kalenderår og korrigeret for C-13. Konventionel datering $i$ C-14 år er 1050 e. Kr. Prøven er lavet på trækul/grene med forholdsvis lav egenalder.

23) Upubliceret hovedfagsspeciale af Søren Mainz ved Institut for Forhistorisk Arkæologi, Århus Universitet. 1989.

24) M. Bencard m.fl.: Wikingerzeitliches Handwerk im Ribe. Acta. Arch. Vol. 49. 1979, p. 113-138.

25) Kemiske analyser lavet af konserveringsanstalten på Moesgård til specialet omtalt i note 23.

26) E. Roesdahl: Danmarks vikingetid. 1980. Fundliste 2, p. $260 \mathrm{ff}$.

27) J.T. Møller: Han Herrederne - et gammelt ørige. Aggersborg gennen 1000 år. 1986, p. 19, fig. 5.

28) Venligt meddelt af udgraveren cand. phil. Jytte Nielsen.

29) J. Olsen: Furs historie fra Middelalder til udskiftning. Fur Ø’s Spare- og Lånekasse gennem 100 år. 1973.

30) M.Breiner: Ålefiskeri fra Fur for 1920. MIV 5, 1975, p. 84, fig. 12.

31) Venligst meddelt af tidligere museumsleder Magne Breiner.

\section{FUNDLISTE}

Sammen med fig. 1 giver fundlisten en oversigt over bebyggelser fra yngre germaner- og/eller vikingetid i den vestlige del af Limfjorden.

1. Aggersborg

2. Ørbæk

3. Vangstedgaard: AHM 146

4. Thorsholm: SMS 76 A

5. Jebjerg: SMS 361 A

6. Ballingvej: SMS $426 \mathrm{~A}$

7. Sønderup: SMS $405 \mathrm{~A}$

8. Harrevig

9. Skarregård: MHM $1258 \mathrm{X}$

10. Ndr. Dråby: MHM $774 \mathrm{X}$

11. Vildsund øst: MHM $571 \mathrm{X}$

12. Galtrup: MHM $1126 \mathrm{X}$

13. Karby: MHM $64 \mathrm{X}$ m.fl.

14. Løngård: MHM $841 \mathrm{X}$

15. Dalgård-Fårup: MHM 1171 X m.fl.

16. Bybjerggård: MHM $706 \mathrm{X}$ 


\section{Nederby on Fur, a village founded in the later Iron Age}

\section{A contribution to knowledge of Viking settlement in the western Limfjord}

In 1987-89 5500 $\mathrm{m} 2$ of the present village of Nederby (fig. 1-2) were excavated in two main excavation areas at Fur Kirkevej (fig. 3) and Bjerregårdsbakke (fig. 4). Altogether two longhouses, 28 pit huts, ditches, and many pits came to light. House I is the older of the two longhouses. Judging from the arrangement of the last pair of roof-bearing posts before the end wall it must date from the late part of the later Germanic period. House II is a singleaisled structure with roof-bearing wall posts, which may be dated to the end of the 11 th century or around the year 1100 . Intersections between pit huts show that these were not all in simultaneous use (fig. 5), and to judge from the $\mathrm{C}-14$ datings they were built over a period of about 300 years.

The pottery included two whole pots and 409 sherds, of which 64 were rim sherds and were datable to the later Germanic and Viking periods, and the early Middle Ages (fig. 6-9). The remaining material consisted mainly of iron slag, of which about $50 \mathrm{~kg}$ were found in 19 different pits and pit huts. Of particular interest was a blacksmith's hearth with $16 \mathrm{~kg}$ of slag including an angular hearth slag, planoconvex furnace bottom slags, and sintered clay from the sides of the pit. The other finds were very few, consisting only of a couple of rotary querns, bones of horse and pig, a little carbonized corn, a glass bead, and a few objects of bronze and iron.

Today 24 sites with remains of settlement in the later Germanic and/or Viking periods are known in the western part of the Limfjord. Nearly half are coastal settlements. The fjord may therefore have been of considerable importance. At Aggersborg and Nørregård so much imported soapstone has been found that the places can be classed as trading sites. Nederby on the other hand has produced so few finds that no more than local trade is indicated.

The recovery of a 10th century stirrup at Lille Knudshoved on west Fur implies that we here have a fishery landing site from the Viking period, comparable with the many landing sites that existed along the coasts of the island before fishery became mechanized at about the turn of the century. If fishery was a significant economic factor as early as in Viking times it could have found expression in a structure and continuity of settlement that is different from that in other parts of the country.

The discoveries at Nederby and Lille Knudshoved have underlined a deficiency in the sources, for the importance of fishery cannot be clarified by digging in the actual settlements. The Nederby exvavations have also underlined how important it is for excavations of Viking settlements to take place as surface clearance and not merely as the digging of small pits for dating purposes. Our present knowledge of Viking settlement is based principally on the extensive excavations of farming settlements in central and western Jutland and in Frisian-influenced settlements of the Ribe area. The many coastal communities on the Limfjord are an important supplement to these. The present state of research is insufficient for wide conclusions to be drawn, but suggests that fishery, small craft navigation, and trade were important for the area as early as in Viking times.

\author{
John Brinch Bertelsen \\ Fur Museum \\ Oversattelse: David Liversage \\ Tegning: Sonja Justesen og Margrethe Larsen
}


